\title{
Determination of the 'critical region' for cat-like cry of Cri-du-chat syndrome and analysis of candidate genes by quantitative PCR
}

\author{
Qingfa $\mathrm{Wu}^{1,2}$, Erik Niebuhr ${ }^{1}$, Huanming Yang ${ }^{2}$ and Lars Hansen ${ }^{\star, 1,3}$
}

\author{
${ }^{1}$ Department of Medical Genetics, Institute of Medical Biochemistry and Genetics, Panum Institute, University of \\ Copenhagen, Copenhagen N, Denmark; ${ }^{2}$ Beijing Genomics Institute, Chinese Academy of Sciences, Beijing, China; \\ ${ }^{3}$ Wilhelm Johannsen Centre for Functional Genome Research, Institute of Medical Biochemistry and Genetics, Panum \\ Institute, University of Copenhagen, Copenhagen N, Denmark
}

Cri-du-chat (CDC, OMIM 123450) is a chromosomal syndrome that results from partial deletions on the short arm of chromosome 5. The clinical features of CDC normally include high-pitched cat-like cry, mental retardation, microcephaly, hypertelorism and epicanthic folds. The cat-like cry is the most prominent clinical characteristic in newborn children and is usually considered as diagnostic for the CDC syndrome. Using a strategy of 'phenotype dissection', the critical region for cat-like cry was mapped to the chromosomal segment 5p15.3-5p15.2 in previous reports. In this study, the distal breakpoints of two interstitial deletions in two clinical distinctive CDC patients are analysed, one with and one without the catlike cry. Using PCR, the critical region for the cat-like cry is mapped to a short $640 \mathrm{kbp}$ region on chromosome $5 \mathrm{p}$. Genome analysis of this critical region reveals a gene-rich sequence containing five known genes, five putative genes and three spliced EST sequences, altogether 71 predicted exons. Three genes, FLJ25076, a homolog to a ubiquitin-conjugating enzyme UBC-E2, FLJ20303, a nucleolar protein NOP2, which may play a role in the regulation of the cell cycle and MGC5309, a protein with similarity to Nut2, a Drosophila transcriptional coactivator, have been characterized and expression profiles determined by quantitative PCR. These results suggest that one candidate gene, FLJ25076, encodes a ubiquitinconjugated enzyme E2 type, which is locally expressed in thoracic and scalp tissues. The other two genes are expressed uniformly in all tissues tested, which suggest that they are housekeeping genes.

European Journal of Human Genetics (2005) 13, 475-485. doi:10.1038/sj.ejhg.5201345

Published online 19 January 2005

Keywords: Cri-du-chat (CDC); cat-like cry critical region; quantitative PCR; ubiquitin-conjugated enzyme E2

\section{Introduction}

Cri-du-chat syndrome (CDC, OMIM 123450) first described by Lejeune in $1963^{1}$ is a well-described partial aneusomy, resulting from deletions on the short arm of chromosome

${ }^{*}$ Correspondence: Dr L Hansen, Department of Medical Genetics, Institute of Medical Biochemistry and Genetics, Panum Institute, University of Copenhagen, Blegdamsvej 3b, DK-2200 Copenhagen N, Denmark. Tel: + 45 35327810; Fax: + 45 35327845;

E-mail: larsh@medgen.ku.dk

Received 23 March 2004; revised 8 October 2004; accepted 12 October 2004
5. The typical features of CDC normally include a highpitched cat-like cry, microcephaly, round face, hypertelorism, micrognathia, epicanthic folds and mental retardation. ${ }^{1,2}$ The high-pitched monotone cry is the most prominent clinical characteristic and is usually considered as the hallmark of CDC in newborn children. ${ }^{2}$ CDC is the most common human classical deletion syndrome with an incidence varying from 1 in 20000 to 1 in 50000 births. $^{2}$

The majority of large deletions on the short arm of chromosome 5 are associated with CDC. The deletions vary in size from less than $10 \%$ to more than $80 \%$ of the short 
arm in CDC patients, and the corresponding phenotypes vary normally from a subset of clinical features to the complete spectrum of CDC. ${ }^{3}$ Previous cytogenetic analyses have identified 'critical regions' that are important and correspond to different clinical facets of the CDC phenotype.

A general region called the CDC 'critical region' or CdCCR is identified in most studies and is located on chromosome 5 p15.2. ${ }^{4-7}$ Deletions of genes in this region are assumed to be associated with changes in facial features and severe mental retardation and general CDC features. The markers D5S23, D5S721, D5S769 and D5S791 delimit the CdCCR region. ${ }^{4,5}$ A larger region including the CdCCR and additional childhood facial dysmorphism as well as moderate mental retardation is mapped to D5S24, D5S713, D5S755 and D5S706. ${ }^{6}$

More detailed studies have identified the proximal part of 5 p15.3 as the 'critical region' for cat-like cry and a segment within $5 \mathrm{p} 15.2$ as responsible for the 'critical region' for mental retardation. ${ }^{4,5}$ Several of these reports map the 'critical regions' to different positions on $5 p$ and the inconsistency is a serious problem in defining genes involved in the different phenotypical characteristics. The 'critical region' for the cat-like cry has been mapped both to the proximal part of $5 \mathrm{p} 15.3$ and the distal part of 5p15.2. ${ }^{4-6}$ The suggested 'critical region' for the cat-like cry in the overlapping region between 5p15.2 and 5p15.3 suggests haploinsufficiency for one or several genes within this region causing the cat-like cry phenotype. Further, regions for childhood facial dysmorphism, moderate mental retardation, for adult facial dysmorphism and severe mental retardation are mapped to two other segments on $5 \mathrm{p} 15.2$, and in addition, a distinct fourth region for speech delay is hypothesized as being on the distal portion of $5 \mathrm{p} 15.3 .^{6}$

Using a combination of somatic hamster hybrid cell lines, STS markers and PCR, the precise locations of two distal breakpoints are defined in two CDC patients with interstitial deletions, one with and one without the cat-like cry. This results in a precise map in between the breakpoints spanning $5 \mathrm{p} 15.3-5 \mathrm{p} 15.2$, a region that corresponds to $640 \mathrm{~kb}$, which plays a role in the cat-like cry phenotype.

\section{Materials and methods \\ Patients and clinical features}

The two CDC patients were selected from a large group of CDC patients analyzed by karyotype and array-comparative genome hybrid (CGH) analysis (unpublished data). Both cases, case 49 and case 252, have interstitial deletions on chromosome 5p. Case 49 (46, XY, del (p14.1p15.31)) has a typical cat-like cry, typical facial CDC features and severe mental retardation (IQ <20); case 252 (46, XY, del (p15.1p15.31)) has a normal cry and facial features and moderate mental retardation (IQ $\approx 50$ ). Their clinical features remain stable before and after their 5th year, and both have normal speech and language, which is typical for interstitial deletions.

\section{Biological material}

Lymphocytes were transformed with $\mathrm{EB}$ virus, and $\mathrm{EB}$ virus-transformed lymphoblastoid cell lines were fused with the Chinese hamster cell line UCW56. ${ }^{8}$ Somatic cells containing the specific deleted chromosome 5 in case 49 and case 252 were cultured and genomic DNA was isolated by routine methods. Positive control genomic DNA including intact human chromosome 5 was isolated from somatic cell hybrids, and negative control genomic DNA was isolated from the Chinese hamster cell line UCW56. ${ }^{8}$

\section{Molecular analysis by PCR}

Oligonucleotide primers were designed using the software OLIGO and synthesized by TAG Copenhagen A/S. Optimal annealing temperatures for primer pairs were determined by PCR temperature gradients using normal human genomic DNA as template. Reactions were performed in $15 \mu \mathrm{l}$ volumes containing $10 \mathrm{ng}$ genomic DNA isolated from somatic cell hybrid, $0.6 \mu \mathrm{M}$ of each primer, $1 \mathrm{U}$ Taq DNA polymerase (Promega), $0.6 \mathrm{~mm}$ dNTP, $10 \mathrm{mM}$ Tris- $\mathrm{HCl}$ (pH 8.3), $50 \mathrm{mM} \mathrm{KCl}$ and $1.25 \mathrm{mM} \mathrm{MgCl}_{2}$. Thermocycling was performed on an MJ-Research PTC-200, initial denaturation was at $95^{\circ} \mathrm{C}$ for $2 \mathrm{~min}$, followed by 40 cycles: $30 \mathrm{~s}$ at $95^{\circ} \mathrm{C} ; 30 \mathrm{~s}$ at optimized $T_{\mathrm{m}} ; 45 \mathrm{~s} 72^{\circ} \mathrm{C}$ and final extension for $7 \mathrm{~min}$ at $72^{\circ} \mathrm{C}$, to complete the PCR. The PCR products were visualized in $2 \%$ agarose gel stained by ethidium bromide.

\section{In silico DNA analysis}

Genomic DNA sequences were analyzed with publicly available tools. The DNA sequence homology queries were carried out using BLAST algorithms against GenBank, NCBI (http://www.ncbi.nlm.nih.gov/blast). Identification of dispersed and tandem repeats was carried out by the RepeatMask (http://repeatmasker.genome.washington.edu/cgi-bin/RepeatMasker) and Tandem Repeat Finder (http://c3.biomath.mssm.edu/trf.html), and exons located in putative gene regions were predicted by Genscan (http:// bioweb.pasteur.fr/seqanal/interfaces/genscan.html). Protein analysis for possible physiological functions was carried out using Interpro Database (http://www.ebi.ac.uk/interpro). CpG-island analysis was performed using the CpG Island Searcher (http://cnt.hsc.usc.edu/cpgislands/).

\section{Quantitative analysis and real-time PCR}

Real-time PCR was carried out using a DNA Engine Opticon $^{\mathrm{TM}}$ PCR machine (MJ-Research). Total RNA was isolated from a trisomy 13 embryo and reverse transcription was performed using an $\mathrm{ht} 11 \mathrm{v}\left([\mathrm{T}]_{11}[\mathrm{G}, \mathrm{C}, \mathrm{A}]\right)$ primer and Superscript II according to the manufacturer's protocol 
(Invitrogen). Real-time PCR was performed according to the commercial kit manual (Roche), and detected by staining with SYBR Green I. Real-time PCR was carried out on 11 fetal tissues under optimal conditions. Automatically produced standard curves were constructed using dilution series of identical DNA fragments of each PCR fragment, and calculation of concentration values of samples carried out.

\section{Results}

Mapping of the candidate regions by PCR

Using microarray-CGH analysis approaches, the distal breakpoints in case 49 and case 252 could be located between the STS markers D5S464 and D5S676 (Figure 1, unpublished results). Choosing different STS markers in the region made it possible to draw a refined map of the two distal breakpoints. The STS primer pair locations were

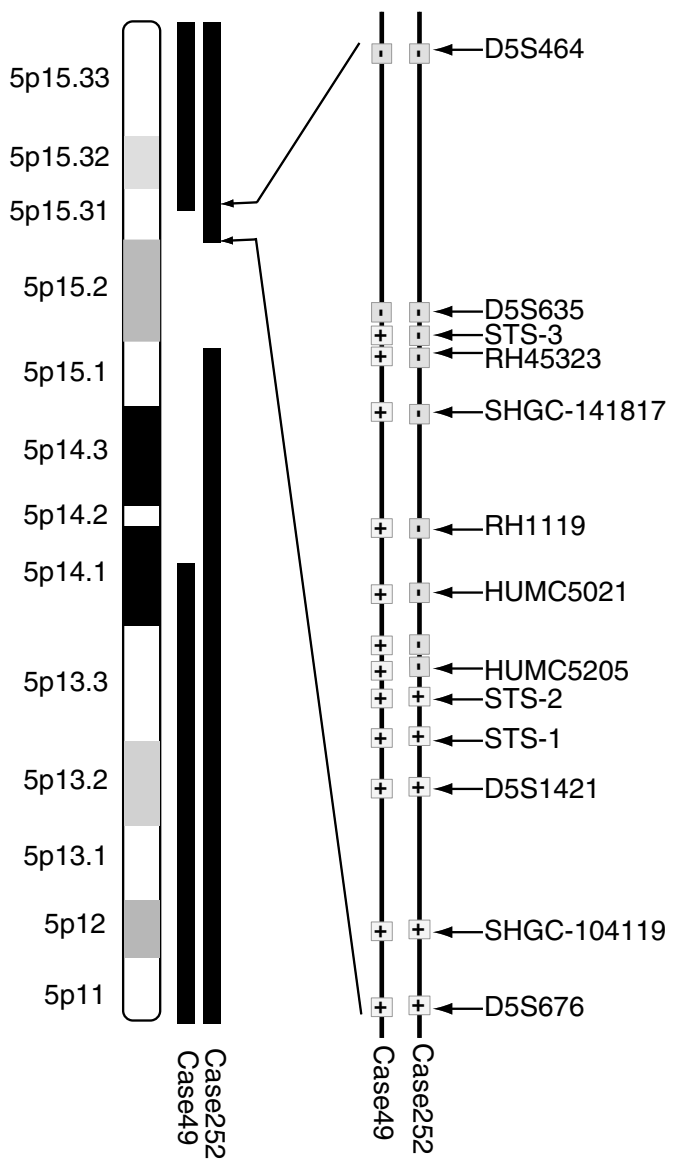

Figure 1 Cytogenetic map of the Cri-du-chat region on chromosome $5 \mathrm{p}$. The interstitial deleted regions in case 49 and case 252 are shown together with the 13 STS markers used for mapping the exact breakpoints on the cytogenetic map. Boxes with plus mark denoted STS markers detected and minus denotes STS markers not detected. evenly distributed throughout the region from the end point markers D5S464 to D5S676 (Table 1), and used to narrow down the candidate region testing for the presence or absence of each of the 13 STS markers in hamster hybrid cell lines of case 49 and case 252.

Localization of the distal breakpoint of the interstitial deletion in case 49 chromosome 5 in hamster hybrid cell line UCW56

The STS marker D5S635 is missing and the marker STS-3 is detected, and analyzed by PCR in case 49 hamster hybrid cell lines DNA (Figure 1). These results delimit the position of the $5 p$ distal breakpoint in case 49 to a 35072 bp region between the markers D5S635 and STS-3, both located in 5p15.32. Exon 1, intron 1 and most of exon 2 of the cDNA clone FLJ33360 are located in this region (Table 2), and the gene is possibly destroyed by the distal breakpoint in case 49. No other open-reading frames or cDNA clones can be found in this region.

Localization of the distal breakpoint of the interstitial deletion in case 252 chromosome 5 in hamster hybrid cell line UCW56

PCR analysis of hamster hybrid cell lines DNA for case 252 showed the presence of marker STS-2 and the lack of marker HUMC5205 (Figure 1). These results delimit the distal breakpoint to a $54462 \mathrm{bp}$ region located in the cytogenetic band 5p15.31. No genes or open-reading frames are located in this region.

In silico DNA sequence analysis of the critical cat-like cry region

Mapping the distal breakpoint positions in case 49 and case 252 delimits the 'critical region' for the cat-like cry to a $638634 \mathrm{bp}$ long DNA sequence between the markers D5S635 and STS-2. BLAST analysis of the DNA sequence, by masking for repeats and retroviral elements, identified more than 25 different mRNA clones and 893 EST sequences annotated in GenBank, which in total represent five known genes and five putative genes, from now on named I, II, III, IV and V (Figure 2).

The five open-reading frames representing genes with known or inferred functions are SRD5A1, POLS, FLJ20303, FLJ25076 and MGC5309, and the putative genes I-V (Figure 2, Table 2) are all represented by mRNA, IMAGE or FIS clones and supported by EST sequences from GenBank. Analysis of protein sequence and structure of the putative genes $\mathrm{I}-\mathrm{V}$ products and BLAST searches did not reveal any homology with known proteins or domains. These unknown genes are excluded in the further analysis of the cat-like cry phenotype.

SRD5A1 is a steroid 5-alpha-reductase (OMIM, \#184753, EC1.3.99.5), which catalyzes conversion of testosterone into the more potent androgen, dihydrotestosterone (DHT). There are two isoforms of the enzyme: SRD5A1 is 
Table 1 DNA sequence for the STS primers sets used to identify the cat-cry like 'critical region'

\begin{tabular}{|c|c|c|c|c|c|c|c|c|}
\hline No. & Marker name & Alias & Location on chr5 & & equence & $\begin{array}{l}\text { Optimal } T_{m} \\
\left({ }^{\circ} \mathrm{C}\right)\end{array}$ & $\begin{array}{l}\text { PCR size } \\
\text { (bp) }\end{array}$ & Source \\
\hline 1 & D5S464 & $\begin{array}{l}\text { AFM } 112 \times \text { e3, SHGC- } \\
20246 \text { RH49495, } \\
\text { RH30895 }\end{array}$ & $5889523-5889722$ & $\begin{array}{l}\mathrm{F} \\
\mathrm{R}\end{array}$ & $\begin{array}{l}\text { CAATTCCCATCATCAGCCTC } \\
\text { TTGAGGAAATTAAGGCAGGG }\end{array}$ & 57 & $117-137$ & UniSTS \\
\hline 2 & D5S635 & AFM276yb9, RH42433 & $6365349-6365645$ & $\begin{array}{l}F \\
R\end{array}$ & $\begin{array}{l}\text { TAACATCCTCCAGGGC } \\
\text { GCTCATTACACTACAGTTACTाT }\end{array}$ & 57 & $159-170$ & UniSTS \\
\hline 3 & STS3 & - & $6400135-6400367$ & $\begin{array}{l}\mathrm{F} \\
\mathrm{R}\end{array}$ & $\begin{array}{l}\text { CAGCATGTTTGGGAGGAAAG } \\
\text { CAAATGTGGCATCTCAAGGAG }\end{array}$ & 62 & 263 & This study \\
\hline 4 & $\mathrm{RH} 45323$ & stSG15996 & $6428068-6428200$ & $\begin{array}{l}\mathrm{F} \\
\mathrm{R}\end{array}$ & $\begin{array}{l}\text { CCTGCCTTTTCTGTACCCT } \\
\text { TGGCCTCAATTATAAAATTCGA }\end{array}$ & 57 & 124 & UniSTS \\
\hline 5 & SHGC-141817 & - & $6527186-6527386$ & $\begin{array}{l}\mathrm{F} \\
\mathrm{R}\end{array}$ & $\begin{array}{l}\text { TATTTCTTGCCAATGCTCAGACA } \\
\text { AAGCCTGTGGGGTTATCACTATG }\end{array}$ & 65 & 308 & UniSTS \\
\hline 6 & RH41119 & - & $6722006-6722205$ & $\begin{array}{l}\mathrm{F} \\
\mathrm{R}\end{array}$ & $\begin{array}{l}\text { CTTTIGTAGATTTTGAGTITTCC } \\
\text { ATTGATAACAGGTACAGGCTATG }\end{array}$ & 62 & 243 & UniSTS \\
\hline 7 & HUMC5021 & L28187 & $6850007-6850206$ & $\begin{array}{l}\mathrm{F} \\
\mathrm{R}\end{array}$ & $\begin{array}{l}\text { AAGCTTCCGTTCCGCCTTCTGTATC } \\
\text { TAATCCATCCAGGAAAGGGCTACCC }\end{array}$ & 57 & 208 & UniSTS \\
\hline 8 & HUMC5205 & L28252 & $6949482-6949681$ & $\begin{array}{l}\mathrm{F} \\
\mathrm{R}\end{array}$ & $\begin{array}{l}\text { AACTGTCCTTGGGATGTATAAC } \\
\text { AAAAGGCAGAAGTGGCATTTCTG }\end{array}$ & 57 & 80 & UniSTS \\
\hline 9 & STS2 & - & $7003686-7003985$ & $\begin{array}{l}\mathrm{F} \\
\mathrm{R}\end{array}$ & $\begin{array}{l}\text { TCCCCGTTGGTGAACTTITAG } \\
\text { CGCCAAATTACTGATGCTCTG }\end{array}$ & 62 & 267 & This study \\
\hline 10 & STS1 & - & $7061904-7061996$ & $\begin{array}{l}\mathrm{F} \\
\mathrm{R}\end{array}$ & $\begin{array}{l}\text { AATCCAGCCCCACTTCAAAAA } \\
\text { TGTTCTGGCCACTCGGGGTAG }\end{array}$ & 57 & 100 & This study \\
\hline 11 & D5S1421 & WI-1755 & $7145885-7146084$ & $\begin{array}{l}\mathrm{F} \\
\mathrm{R}\end{array}$ & $\begin{array}{l}\text { GTTTTAAACTGGGTCACTTGTTCC } \\
\text { CCACCAGAGCCAATGGAG }\end{array}$ & 57 & 309 & UniSTS \\
\hline 12 & SHGC-104119 & RH123052 & $7370668-7370868$ & $\begin{array}{l}\mathrm{F} \\
\mathrm{R}\end{array}$ & $\begin{array}{l}\text { ATAAGGCATCAGGAGTAAAGGGG } \\
\text { TACCACAACATCTGTTGCCATTC }\end{array}$ & 65 & 275 & UniSTS \\
\hline 13 & D5S676 & $\begin{array}{l}\text { AFM347yg9, RH30574 } \\
\text { SHGC-1823 }\end{array}$ & $7492332-7492531$ & $\begin{array}{l}\mathrm{F} \\
\mathrm{R}\end{array}$ & $\begin{array}{l}\text { ACCACCCCCTGATTAAATTA } \\
\text { AАСTTTCTCCGTGACACTTTC }\end{array}$ & 57 & 285 & UniSTS \\
\hline
\end{tabular}


Table 2 GenBank Accession numbers and proposed biological functions for genes in the cat-like cry 'critical region'

\begin{tabular}{|c|c|c|c|c|c|c|c|}
\hline RefSeq gene & $\begin{array}{l}\text { GenBank Accession } \\
\text { nos. }\end{array}$ & Comments & Biological function & $\begin{array}{l}\text { mRNA size } \\
\quad(b p)\end{array}$ & Strand & Chr5 position & $\begin{array}{l}\text { Exon } \\
\text { number }\end{array}$ \\
\hline$D 55635$ & $\begin{array}{l}\text { AK090679a } \\
\text { AX746570 }\end{array}$ & $\begin{array}{l}\text { Homo sapiens CDNA } \\
\text { FLJ33360 }\end{array}$ & $\begin{array}{l}\text { Unknown, exon2 } \\
-\end{array}$ & 2419 & - & $\begin{array}{c}6363292- \\
6390143 \\
6365349- \\
6365645\end{array}$ & 2 \\
\hline I & $\begin{array}{l}\text { AK090679 } \\
\text { AX746570 }\end{array}$ & $\begin{array}{l}\text { Homo sapiens cDNA } \\
\text { FLJ33360, the mRNA } \\
\text { sequences are not } \\
\text { supported by EST } \\
\text { sequences }\end{array}$ & Unknown, exon1 & 2419 & - & $\begin{array}{c}6363292- \\
6390143\end{array}$ & 2 \\
\hline STS-3 & & & - & & & $\begin{array}{c}6400135- \\
6400367\end{array}$ & \\
\hline II & AK094742 & $\begin{array}{l}\text { Homo sapiens CDNA } \\
\text { FLJ37423, the mRNA } \\
\text { sequences are not } \\
\text { supported by EST } \\
\text { sequences }\end{array}$ & Unknown & 2463 & + & $\begin{array}{c}6414883- \\
6417346\end{array}$ & 1 \\
\hline MGC5309 & $\mathrm{BC} 003353^{\mathrm{a}}$ & $\begin{array}{l}\text { Homo sapiens, similar to } \\
\text { Drosophila gene CG5057, } \\
\text { clone MGC:5309 }\end{array}$ & $\begin{array}{l}\text { Hypothetical protein, } \\
\text { similarity to Nut2 from } \\
\text { Drosophila, } \\
\text { transcriptional } \\
\text { coactivator KOG } 3046, \\
\text { subunit of SRB } \\
\text { subcomplex of RNA } \\
\text { polymerase II }\end{array}$ & 805 & - & $\begin{array}{c}6425014- \\
6431377\end{array}$ & 4 \\
\hline FLJ25076 & $\begin{array}{l}\text { AK057805 a } \\
\text { AK096612 } \\
\text { BC029403 }\end{array}$ & $\begin{array}{l}\text { Homo sapiens cDNA } \\
\text { FLJ25076, homolog to } \\
\text { Drosophila gene CG4502 }\end{array}$ & $\begin{array}{l}\text { Homology to a ubiquitin- } \\
\text { conjugating enzyme E2 } \\
\text { homolog, ubiquitin- } \\
\text { protein ligase (post- } \\
\text { translational } \\
\text { modification, protein } \\
\text { turnover, chaperones). }\end{array}$ & 1471 & + & $\begin{array}{c}6502003- \\
6545443\end{array}$ & 2 \\
\hline III & BC043253 & $\begin{array}{l}\text { Homo sapiens, clone } \\
\text { IMAGE: 5296404, mRNA }\end{array}$ & Unknown & 1904 & + & $\begin{array}{c}6636443- \\
6640518\end{array}$ & 3 \\
\hline FLJ20303 & $\begin{array}{l}\text { NM_017755 } \\
\text { AK023994 } \\
\text { AL137737 } \\
\text { AK000310 } \\
\text { BC001041 } \\
\text { AK055456 }\end{array}$ & $\begin{array}{l}\text { Homo sapiens } \\
\text { hypothetical protein } \\
\text { FLJ20303 (FLJ20303), } \\
\text { mRNA }\end{array}$ & $\begin{array}{l}\text { Hypothetical protein FLJ } \\
20303, \text { nucleolar protein } \\
\text { NOP2, may play a role in } \\
\text { the regulation of the cell } \\
\text { cycle and the increased } \\
\text { nucleolar activity that is } \\
\text { associated with the cell } \\
\text { proliferation, putative } \\
\text { methyltransferase NCL1 }\end{array}$ & 3216 & - & $\begin{array}{c}6652091- \\
6684819\end{array}$ & 18 \\
\hline SRD5A1 & $\begin{array}{l}\text { NM_001047 } \\
\text { AF1 } 13128 \\
\text { BC007033 } \\
\text { BC008673 } \\
\text { AF052126 } \\
\text { M32313 } \\
\text { B C006373 } \\
\text { BT006834 } \\
\end{array}$ & $\begin{array}{l}\text { Steroid-5-alpha- } \\
\text { reductase 1, (SRD5A1), } \\
\text { mRNA }\end{array}$ & $\begin{array}{l}\text { Homo sapiens steroid-5- } \\
\text { alpha-reductase, alpha } \\
\text { polypeptide } 1(3-\text { oxo-5 } \\
\text { alpha-steroid delta } 4- \\
\text { dehydrogenase alpha 1) }\end{array}$ & 2222 & + & $\begin{array}{c}6686301- \\
6722411\end{array}$ & 5 \\
\hline
\end{tabular}


located on chromosome 5 and SRD5A2 is located on chromosome 2p23. ${ }^{9}$ Microarray expression data for SRD5A1 show expression in the fetal brain, thalamus, scalp and skin. ${ }^{10}$ The protein is an integral membrane protein located in the microsomal intracellular fraction and the protein contains an amino-terminal signal peptide domain, a steroid dehydrogenase domain and four transmembrane $\alpha$-helixes. ${ }^{11}$

The gene POLS, also known as POLK, TRF4, LAK-1, TRF41 or $5 \_6789904$, encodes a polymerase of the sigma family (OMIM, \#605198). The polymerase has DNA-binding activity, and is involved in DNA replication and chromosome cycle. ${ }^{12,13}$ The protein contains a nucleotidyltransferase domain and a PAP/25A-associated domain, which is described as topoisomerase 1 related. ${ }^{11}$

MGC5309 is homologous with the Drosophila gene CG5057, and therefore probably codes for a transcriptional coactivator that is a subunit of SRB subcomplex of RNA polymerase II. The hypothetical protein contains a signal peptide as the only identifiable domain, ${ }^{11}$ and is expressed in the lens, retina and cerebellar cortex according to the microarray data. ${ }^{10}$

FLJ25076 corresponds to the Drosophila gene CG4502 and is homologous with a ubiquitin-conjugating enzyme E2 and is expressed in the human brain frontal cortex, skeletal muscle and also in schizophrenic brain S-11 frontal lobe. ${ }^{14}$ The clone Accession number AK057805 represents only the carboxyl-terminal part of the proteins and the entire protein is represented in GenBank by Accession number XM_059689 and XP_059689. The protein is 267 amino-acid residues long and contains a UBCc domain (a ubiquitin-conjugating enzyme E2, catalytic domain homologues) in its carboxyl-terminal end.

FLJ20303 is a hypothetical protein that is homologous with members of the NOL1/NOP2/sun family. This protein may act as nucleic acid methyltransferase and is involved in cell proliferation and ribosome biogenesis located in the nucleus. ${ }^{10,14}$

\section{Expression profiles}

Three genes, MGC5309, FLJ25076 and FLJ20303, were analyzed by real-time PCR expression profiling. The primer pairs used for the PCR are all spanning introns in the genes to exclude false PCR products generated by contamination of genomic DNA (Table 3). Total RNA from a trisomy 13 embryo was used in the expression studies for the selected genes. Standard titration PCR analyses are performed to normalize the expression data, and variation in the expression of the three genes normalized to the lowest value observed (Figure 3). The relative expression level of MGC5309 and FLJ20303 varies by a factor of 5 as observed in all 11 tissues, and can be considered constant. The expression of FLJ25076 varies in the 11 fetal tissues, highest expression is seen in the thorax, that is, 36 times higher than the lowest expression level seen in the pelvis and 
a

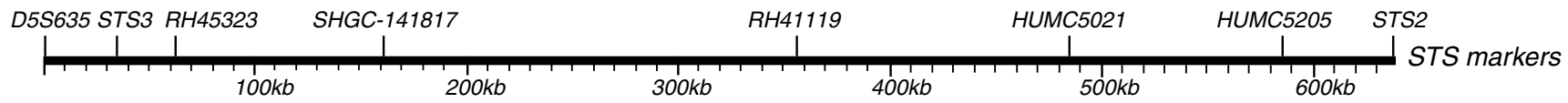

b

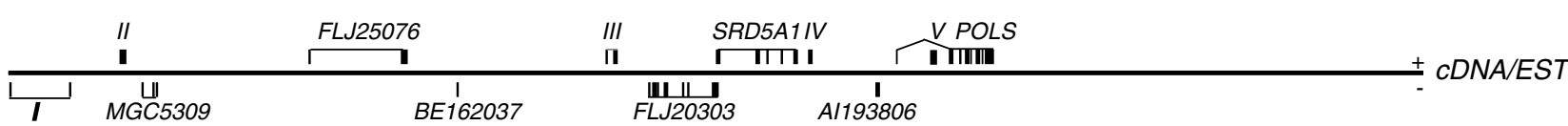

C

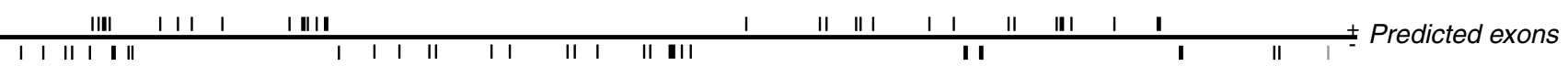

Figure 2 Detailed map of the cat-like cry 'critical region'. (a) STS marker positions, (b) known genes and EST sequences identified and (c) predicted exons identified by Genscan program in the cat-like cry 'critical region'. Plus and minus mark the two different DNA strands.

femur. Low expression is observed in the lever, shoulder, foot and arm-hand, and medium expression was found in the scalp and adrenal gland (Figure 3). The expression data indicate that the two genes MGC5309 and FLJ20303 are the so-called household genes expressed in all tissue types and not likely to be involved in the cat-like cry phenotype. The gene FLJ25076 is expressed differentially in the studied tissues and shows high expression in thorax region. This indicates that the gene is of interest to the cat-like cry phenotype.

\section{Discussion}

Terminal and interstitial deletions of $5 p$ are the two major types of chromosome rearrangement observed in CDC patients. Both types of deletions result in a hemizygous status for the corresponding regions, so that only one intact chromosome 5 is present. One strategy for the identification of genes involved in the clinical characteristics for CDC is to identify genes that are located in the missing regions of the truncated chromosome 5. The clinical variation in CDC patients has led to the postulation of the 'critical regions', where isolated characteristics such as cat-like cry, mental retardation or facial dysmorphy result from the lack of specific genes in distinct regions. This dissects the CDC syndrome into separate individual phenotypes and correlates each phenotype with a 'critical region' such as the specific 'critical region' for the cat-like cry. $^{3}$ Here, we report the fine mapping of telomeric breakpoints in two key CDC persons, both with interstitial deletions and one with and one without the cat-like cry. Also, we try to correlate the mapped region and the suggested genes to previous studies where the cat-like cry 'critical region' has been mapped.

The probes and markers used by Overhauser et al, ${ }^{4}$ Gersh et $a l^{5}$ Church et $a l^{6}$ and Mainardi et $a l^{7}$ are aligned to the completed DNA sequence for chromosome 5p. Table 4 represents the results of these alignments only for marker systems where DNA sequence information is available. Both STS markers, where sequence information from PCR primer sets can locate these, and marker systems using lambda phage DNA clones, where no sequence information is available, have been used in these studies.

Overhauser et al $1994^{4}$ suggested a proximal region on segment 5p15.3 as the cat-like cry 'critical region'. This was based on a study of 49 CDC patients with $5 p$ terminal or interstitial deletions, and especially two patients, one lacking the cat-like cry and one having the cry, delimited the region and were supported by an additional six patients who did not have the cat-like cry. ${ }^{4}$ The region is mapped with the STS marker D5S727 and flanked by the markers D5S11 and D5S12, which are not in the cat-like cry 'region'. The region is $5.9 \mathrm{Mbp}$, but probably much smaller due to the large interval between the markers they have used. The region shows an overlap with the $0.64 \mathrm{Mbp}$ region found in this work (Figure4 and Table 4).

Using the same strategy on four families, Gersh et $a l^{5}$ mapped the cat-like cry to the same proximal region of 5p15.3, using the marker systems D5S13, D5S727, D5S731 and D5S760. Only D5S727 can be located on the 5p chromosome sequence (Table 4), the other three markers are phage clones (not shown in Table 4) and cannot be located on $5 \mathrm{p}$. There is congruence between the 'critical regions' mapped by Overhauser et al and Gersh et al and those in this study (Figure 4).

Church et al postulate a much larger region located in the very proximal part of segment p15.3 and the distal part of 5 p15.2 as the 'critical regions' for the cat-like cry. ${ }^{6}$ This study is based on five CDC families, two having the cat cry and three not. There are no overlaps between the first two reports and the study of Church et al if the map information and STS markers are applied to the $5 \mathrm{p}$ sequence (Figure 4). The three STS markers D5S721, D5S88, D5S821 are continuous in Bin V according to Church et al, giving one continuous region on $5 \mathrm{p}$, but the STS marker D5S821 is located more than $16 \mathrm{Mbp}$ proximal 

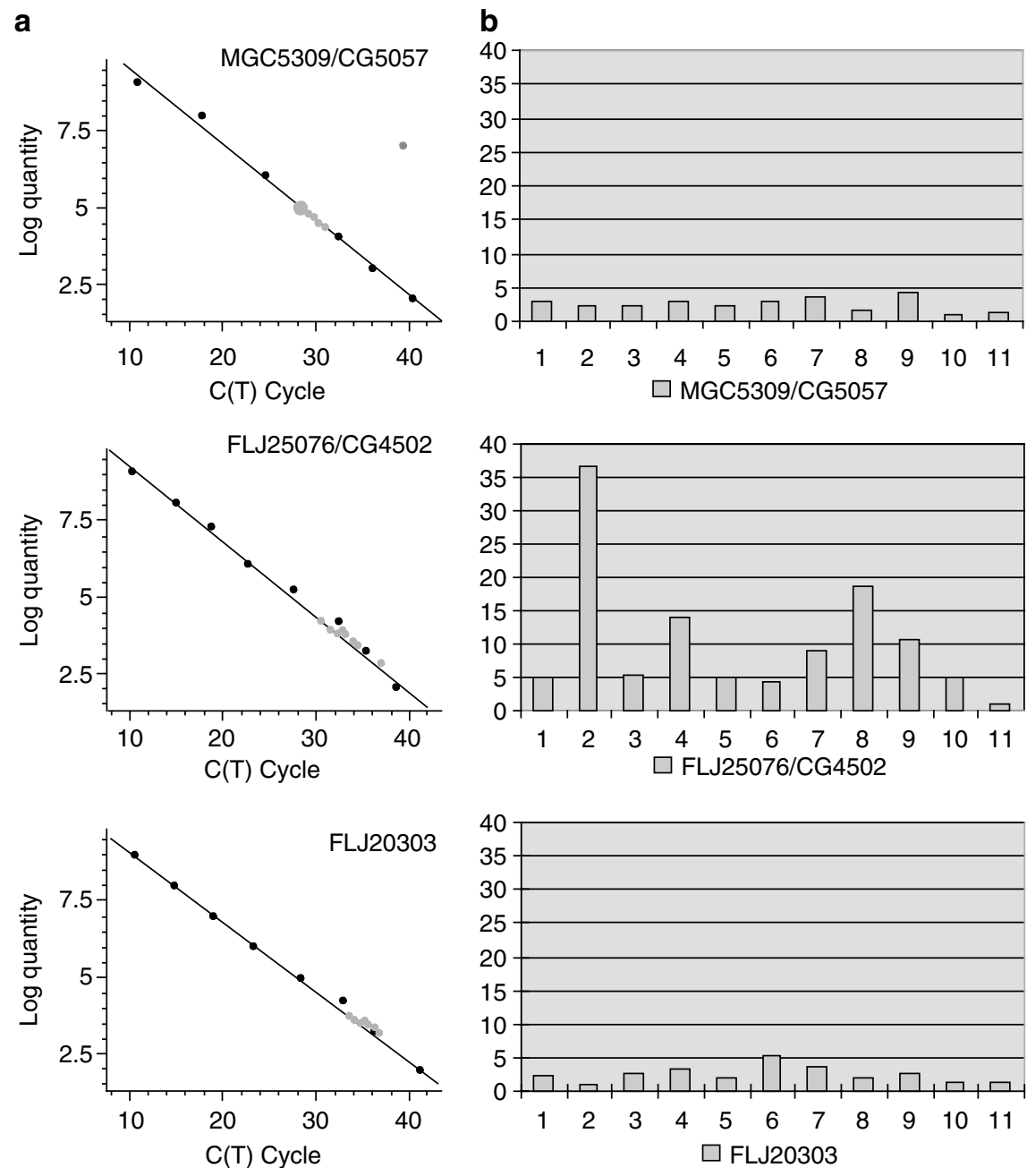

Figure 3 Expression data determined by real-time PCR for the genes MGC5309/CG5057, FL/25076/CG4502 and FLJ20303. Real-time PCR was carried out on total RNA from 11 different human embryos tissues. (a) Graphs representing expression standard curves (black dots) and relative expression for each gene in total RNA (gray dots); (b) diagrams represented normalized value of expression for each gene in total RNA. Tissues: (1) shoulder; (2) thorax; (3) testis; (4) hand; (5) arm-hand; (6) liver; (7) neck; (8) scalp; (9) adrenal gland; (10) foot and (11) pelvis and femur.

to the two other markers. This discrepancy is illustrated in Figure 4 .

In this study, a more precise chromosomal location of the cat-like cry 'critical region' has been obtained using two key CDC patients who have been selected for further analysis. Cytogenetic fine mapping using microarray technology combined with molecular biology technique has been applied to map the distal breakpoints on $5 p$ in case 49 and case 252. These two CDC patients were chosen for three reasons: (a) both patients carry interstitial deletions on chromosome 5p; (b) the two distal breakpoints are relatively closely located at position $5 \mathrm{p} 15.2-$ 5p15.3 located between the STS markers D5S464 and D5S676 (unpublished data), and the distance between D5S464 and D5S676 is limited to $2.4 \mathrm{cM}$ or $1.7 \mathrm{Mbp}$, respectively; and (c) the clinical features of the cat-like cry vary between the two patients. Case 49 has the cat-like cry and case 252 has a normal cry. Using hamster somatic hybrid cell lines and PCR, the distal border in case 49 could be determined to D5S635 and the proximal border in case 252 could be delimited by the marker STS-2 (Figure1 and Table 1). The distance between these two STS marker systems is $640 \mathrm{kbp}$, and the region represents the distal $5 \mathrm{p}$ sequence between the distal breakpoints in case 49 and case 252 . Using this information combined with the results from the map of the breakpoints mapped in case 49 and case 252, accordance is demonstrated to two of the previously mapped regions, ${ }^{4,5}$ whereas the large region ${ }^{6}$ is located proximally to our mapped cat-like cry critical region (Figure 4). 


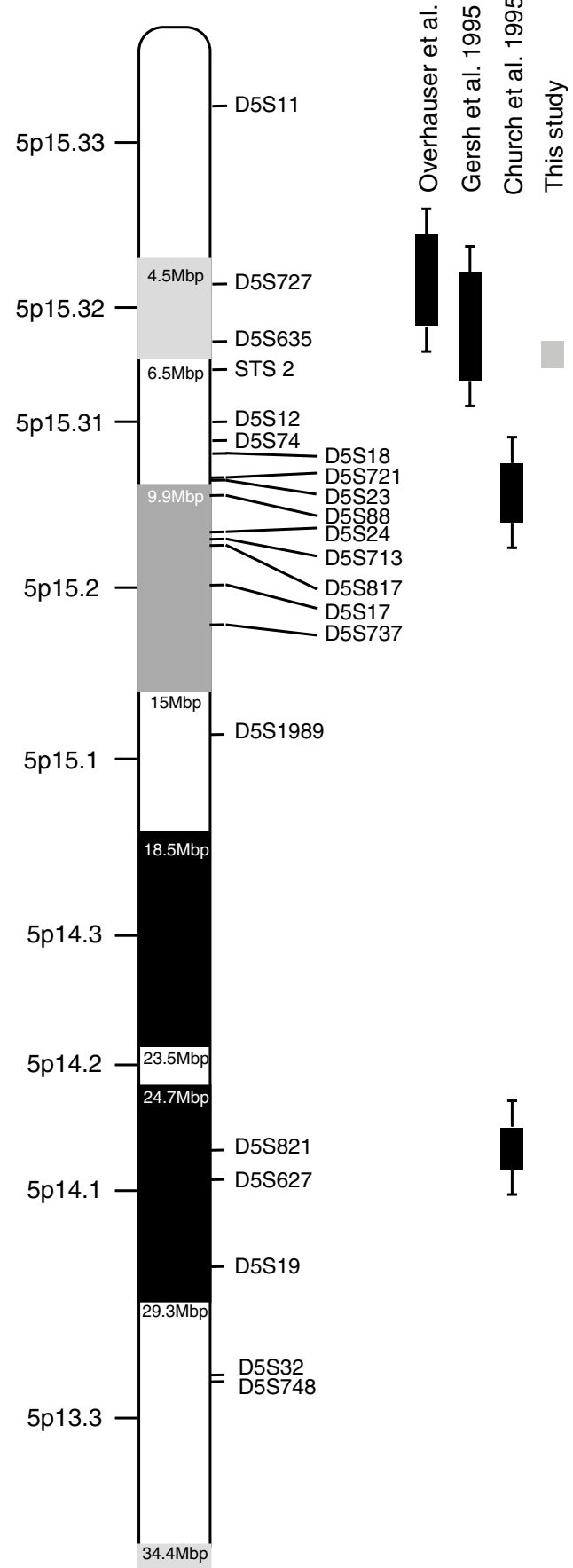

Figure 4 Schematic presentation of the cat-like cry critical region identified in this study and by Overhauser et $a l_{,}{ }^{4}$ Gersh et $a l^{5}$ and Church et al. ${ }^{6}$ Distances from the $5 p$ telomere are shown in Mbp.

The clinical differences between case 49 and case 252 include beside the cat-like cry also facial dysmorphism and differences in mental retardation. This indicates that the comparison of genotype and phenotype is much more complex and the studied region is not exclusively correlated to the cat-like cry. Previous reports locate the "critical regions' for facial and mental retardation to the STS markers D5S18 and N5, which corresponds to a region between 8.2 and $10.3 \mathrm{Mb}$ from $5 p$ telomeric end of the assembled chromosome $5 .{ }^{10}$ Although both case 49 and case 252 lack that segment on 5p15.2, dramatic differences are found in their phenotypes. The deleted region in case 252, which has normal facial features and mild mental retardation, spans only $5 \mathrm{p} 15.31$ and probably most of $5 \mathrm{p} 15.2$. In this case, the remaining genome may compensate for partial functions for those genes mapped on $5 \mathrm{p} 15.2$. This suggests that the pathogenesis is very complex in chromosome diseases.

\section{Surveying several candidate genes}

As an intact chromosome 5 is present for each CDC patient, genes in the 'critical region' probably have to be analyzed as a hemizygotic model system. As haploinsufficiency for CDC-related genes is attributed to developmental delay of specific tissue, it seems useful to investigate expression profiles of candidate genes in fetal tissues. Up to date, the pathogenesis of the abnormal cry is not clear, but varying degrees of larynx and neurological defect have been described in many cases. ${ }^{2}$ If a gene is specifically expressed in some tissues or its expression level varied dramatically among different tissues that relates to malformations found in CDC patients, such as the larynx, pharynx, face and brain, etc., the gene can be considered as a candidate gene in the pathogenic process. Two of the genes in the candidate region play specific biological and physiological roles that do not seem to be related to the cat-like cry phenotype. SRD5A1 (Table 2) plays an important role in sexual differentiation and androgen physiology, converting testosterone to the more potent androgen DHT, leading to the development of male external genitalia through an intriguing program of differentiation, and is involved in syndromes such as male pattern baldness or benign prostate hyperplasia. ${ }^{9,15}$ POLS (Table 2) encodes for a polymerase necessary for several events in DNA metabolism such as chromosome segregation and DNA repair. ${ }^{12,13}$ Five genes coding for not characterized proteins (I-V) have not been investigated. Three genes MGC5309, FLJ20303 and the UBC-E2 homo$\log$, FLJ25076, may be candidate genes for the phenotype changes, and have been chosen to be tested on 11 different embryo tissues. The expression analysis demonstrates that MGC5309 and FLJ20303 are expressed in all tested tissue without significant variation, which implies they possibly belong to a group of housekeeping genes whose function we do not know. The third gene, FLJ25076, is highly expressed in thoracic and scalp tissues (Figure 3). This expression profile may indicate that this gene can be involved in the development of the cat-like cry phenotype. 
Table 3 PCR primer sets used in expression study of three selected genes in the cat-like cry 'critical region'.

\begin{tabular}{|c|c|c|c|c|c|c|}
\hline Gene name & \multicolumn{2}{|c|}{ Primer sequence } & Exon number & PCR size $(b p)$ & Optimal $T_{m}\left({ }^{\circ} \mathrm{C}\right)$ & Optimal $\left[\mathrm{Mg}^{2+}\right] \mathrm{mm}$ \\
\hline MGC5309 & $\begin{array}{l}\mathrm{F} \\
\mathrm{R}\end{array}$ & $\begin{array}{l}\text { GGCAAGATCGACACCATGAAGA } \\
\text { AGGAAGGTGGCGTCAGCACT }\end{array}$ & $2-3$ & 204 & 62 & 2 \\
\hline FLJ25076 & $\begin{array}{l}\mathrm{F} \\
\mathrm{R}\end{array}$ & $\begin{array}{l}\text { CCCTTCTCGCCGCCCTTCAT } \\
\text { GGCGGGGTGACCCAACCATA }\end{array}$ & $2-3$ & 284 & 62 & 2 \\
\hline FLJ20303 & $\begin{array}{l}\mathrm{F} \\
\mathrm{R}\end{array}$ & $\begin{array}{l}\text { CGGCTGGCACAGGAGGGAAT } \\
\text { CCCGCCATCCGCATAAGACG }\end{array}$ & $2-3$ & 242 & 62 & 2 \\
\hline
\end{tabular}

Table 4

\begin{tabular}{|c|c|c|c|c|c|c|c|c|c|}
\hline Name of marker & Cytogenetic position $^{(a)}$ & Chromosome 5 position $^{(b)}$ & Overh & auser et $a l^{(\mathrm{c})}$ & Church et $a \mathrm{r}^{(\mathrm{d})}$ & Gersh & et $a l^{(\mathrm{e})}$ & Markers $^{(f)}$ & Reference \\
\hline D5S11 & p15.33 & 1793887 & - & p15.3 & - & - & p15.3 & STS & 5 \\
\hline D5S13 & - & - & - & - & - & $\mathrm{CC}$ & p15.3 & P & 6 \\
\hline D5S727 & p15.32 & 5121905 & $\mathrm{CC}$ & p15.3 & - & $\mathrm{CC}$ & p15.3 & STS & 6 \\
\hline D5S635 & p15.32 & 6365349 & - & - & - & - & - & STS & This study \\
\hline STS-2 & p15.31 & 7003686 & - & - & - & - & - & STS & This study \\
\hline D5S731, D5S760 & - & - & - & - & - & $\mathrm{CC}$ & $\mathrm{p} 15.3$ & $P$ & \\
\hline D5S12 & p15.31 & 7684497 & - & p15.2 & - & - & - & STS & 5 \\
\hline D5S74 & p15.31 & 8087973 & - & p15.2 & - & - & - & STS & 5 \\
\hline D5S18 & p15.31 & 8226660 & - & p15.2 & - & - & p15.2 & STS & 5,6 \\
\hline D5S721 & p15.31 & 9540407 & - & p15.2 & $\mathrm{CC}$ & - & p15.2 & STS & $5-7$ \\
\hline D5S23 & p15.31 & 9814858 & - & p15.2 & - & - & p15.2 & STS & 5,6 \\
\hline D5S88 & p15.2 & 10020154 & - & p15.2 & CC & - & - & STS & 5 \\
\hline D5S24 & p15.2 & 11144512 & - & p15.2 & - & - & $\mathrm{p} 15.2$ & STS & 5,6 \\
\hline D5S713 & p15.2 & 11569386 & - & p15.2 & - & - & p15.2 & STS & 5,6 \\
\hline D5S817 & p15.2 & 11638214 & - & - & - & - & - & STS & 7 \\
\hline D5S17 & p15.2 & 13946862 & - & p15.1 & - & - & - & STS & 5 \\
\hline D5S737 & p15.2 & 15080403 & - & p15.1 & - & - & - & STS & 5 \\
\hline D5S1989 & p15.1 & 15679213 & - & - & - & - & - & STS & 8 \\
\hline D5S821 & p14.1 & 26096004 & - & - & $\mathrm{CC}$ & - & - & STS & 7,8 \\
\hline D5S627 & p14.1 & 26794303 & - & - & - & - & - & STS & 8 \\
\hline D5S19 & p14.1 & 28401966 & - & p14 & - & - & - & STS & 5 \\
\hline D5S32 & p13.3 & 31266769 & - & p11-13 & - & - & - & STS & 5 \\
\hline D5S748 & p13.3 & 31409110 & - & p13 & - & - & - & STS & 5 \\
\hline
\end{tabular}

Markers (STS) and probes (P) ${ }^{9}$ from Figure 4 used by Overhauser et al, ${ }_{1}^{4}$ Gersh et al, ${ }^{5}$ Church et al ${ }^{6}$ and Mainardi et al, ${ }^{7}$ and this study mapping the catlike cry 'critical region'. The cytogenetic bands ${ }^{(a)}$ and positions ${ }^{(b)}$ refer to NCBI Build 34 and July 2003 version in UCSC Genome Browser [20,21]. ${ }^{\left({ }^{(}, d^{\prime}\right)}$ and ${ }^{(e)}$ refer to mapped regions in different $\mathrm{CdC}$ patients, the cytogenetic positions given by three authors' regions for the region are given. $\mathrm{CC}$ refers to segments deleted in patient with the cat-like cry and are the mapped 'critical region'.

\section{FLJ25076 - the UBC-E2 homologous gene}

FLJ25076 encodes a ubiquitin-conjugating enzyme and comprises 161 amino-acid residues long peptide conserved both in invertebrates and vertebrates. The protein belongs to the group of ubiquitin-conjugating enzymes (UBC or E2 enzymes, EC 6.3.2.19) that catalyze the covalent attachment of ubiquitin to target proteins. A cysteine residue is required for ubiquitin-thiolester formation; this single cysteine in FLJ25076/UBC-E2 is conserved together with the sequence surrounding the cysteine residue. The conserved sequence of known UBC isozymes is found in the FLJ25076/UBC-E2 homolog protein, strongly suggesting that this candidate gene is involved in protein degradations. Proteins designated for proteasome-mediated degradation may be ubiquitinated and this pathway regulates many fundamental processes required in cell viability. ${ }^{16}$
That the UBC-E2 homolog gene is highly expressed in the scalp may infer that it is one of the factors involved in facial features also. This is in accordance with the observation that the $640 \mathrm{Mbp}$ mapped critical region also should include one or several genes responsible for facial features.

Interestingly, a conserved E3 ubiquitin-conjugating enzyme ligase TEB4 (GenBank Accession no. NM_005885) is located in the CDC critical region $5 \mathrm{p} 15.2$ at the position $10.4-10.5 \mathrm{Mbp}$ from $5 \mathrm{p}$ telomere. ${ }^{17}$ The location of another component in the ubiquitin-conjugating degradation pathway just next to the critical region for facial and mental retardation may further support that fact that the proposed UBC-E2 homologous gene FLJ25076 is involved in the cat-like cry phenotype. In addition, the finding of two genes presumably in the same ubiquitin proteosome- 
degrading pathway illustrates clearly that it is much too simple to link only one gene to one phenotypic characteristic as the cat-like cry, the mental retardation or facial dysmorphism. Much more likely several genes are involved in the different clinical characteristics, and this study of the two well-defined CDC patients strongly supports this.

\section{Conclusion}

Detailed analysis of more patients with well-established clinical features is necessary to identify the complex array of genes on chromosome $5 p$ responsible for the CDC syndrome. A combination of the completed DNA sequence for chromosome $5 \mathrm{p}$, the bioinformatic predictions of genes and regulatory elements, and work carried out on CDC patients will in the future probably suggest that more genes are involved in the syndrome. The combination of finemapping breakpoints, closer studies of several key persons with CDC syndrome and bioinformatics will rekindle the discussion of distant regions versus single or multiple genes as the cause of the CDC syndrome.

\section{Acknowledgements}

We thank Anita Niebuhr and Kirsten Winther for technical help with FISH, cell cultures and purification of DNA, and Richard Bousfield, MD is thanked for critical reviewing of the manuscript. Qingfa $W u, M D$ was supported by a grant from The Ministry of Foreign Affairs, Denmark, Danida Fellowship to E. Niebuhr and H. Yang Programme 104.P.3. China.199. The Wilhelm Johannsen Centre for Functional Genome Research was established by the Danish National Research Foundation.

\section{References}

1 Lejeune J, Lafourcade $\mathrm{J}$, Berger $\mathrm{R}$ et al: Trois cas de deletion partielle du bras court d'un chromosome 5. C R Acad Sci (Paris) 1963; 257: 3098-3102.

2 Niebuhr E: The Cri-du-chat syndrome: epidemiology, cytogenetics, and clinical features. Hum Genet 1978; 44: 227-275.
3 Niebuhr E: Cytologic observations in 35 individuals with a 5p- karyotype. Hum Genet 1978; 42: 143-156.

4 Overhauser J, Huang X, Gersh M et al: Molecular and phenotypic mapping of the short arm of chromosome 5: sublocalization of the critical region for the Cri-du-chat syndrome. Hum Mol Genet 1994; 3: 247-252.

5 Gersh M, Goodart SA, Pasztor LM, Harris DJ, Weiss L, Overhauser $\mathrm{J}$ : Evidence for a distinct region causing a cat-like cry in patients with 5p deletions. Am J Hum Genet 1995; 56: 1404-1410.

6 Church DM, Bengtsson U, Nielsen KV, Wasmuth JJ, Niebuhr E: Molecular definition of deletions of different segments of distal $5 \mathrm{p}$ that result in distinct phenotypic features. Am J Hum Genet 1995; 56: 1162-1172.

7 Mainardi PC, Perfumo C, Cali A et al: Clinical and molecular characterisation of 80 patients with $5 p$ deletion: genotypephenotype correlation. J Med Genet 2001; 38: 151-158.

8 Dana S, Wasmuth JJ: Selective linkage disruption in humanChinese hamster cell hybrids: deletion mapping of the leuS, hexB, emtB, and chr genes on human chromosome 5. Mol Cell Biol 1982; 2: 1220-1228.

9 Anderson S, Russell AD: Structural and biochemical properties of cloned and expressed human and rat steroid $5 \alpha$-reductase. Proc Natl Acad Sci USA 1990; 87: 3640-3644.

10 Kent WJ, Sugnet CW, Furey TS et al: The Human Genome Browser at UCSC. Genome Res 2002; 12: 996-1006.

11 Letunic I, Copley RR, Schmidt S et al: SMART 4.0: towards genomic data integration. Nucleic Acids Res 2004; 32: 42-44.

12 Wang Z, Castano IB, De Las Penas A et al: Pol $\kappa$ : a DNA polymerase required for sister chromatid cohesion. Science 2000; 289: 774-779.

13 Walowsky C, Fitzhugh DJ, Castano IB, Ju JY, Levin NA, Christman MF: The topoisomerase-related function gene TRF4 affects cellular sensitivity to the antitumor agent camptothecin. $J$ Biol Chem 1999; 274: 7302-7308.

14 Maximilian D, Sherlock G, Binkley G et al: SOURCE: a unified genomic resource of functional annotations, ontologies, and gene expression data. Nucleic Acids Res 2003; 31: 219-223.

15 Jakimiuk AJ, Weitsman SR, Magoffin DA: $5 \alpha$-Reductase activity in women with polycystic ovary syndrome. J Clin Endocrinol Metab 1999; 84: 2414-2418.

16 Ciechanover A: The ubiquitin-mediated proteolytic pathway. Brain Pathol 1993; 3: 67-75.

17 Swanson R, Locher M, Hochstrasser $\mathrm{M}$ et al: A conserved ubiquitin ligase of the nuclear envelope/endoplasmic reticulum that functions in both ER-associated and Mat $\alpha 2$ repressor degradation. Genes Dev 2001; 15: 2660-2674. 